\title{
Article
}

\section{The effect of time and environmental conditions on Touch DNA}

\author{
Alketbi, Salem Khalifa and Goodwin, William H \\ Available at http://clok.uclan.ac.uk/36280/ \\ Alketbi, Salem Khalifa ORCID: 0000-0002-7773-3953 and Goodwin, William H \\ ORCID: 0000-0002-3632-3552 (2019) The effect of time and environmental \\ conditions on Touch DNA. Forensic Science International: Genetics \\ Supplement Series, 7 (1). pp. 701-703. ISSN 1875-1768
}

It is advisable to refer to the publisher's version if you intend to cite from the work. http://dx.doi.org/10.1016/j.fsigss.2019.10.144

For more information about UCLan's research in this area go to

http://www.uclan.ac.uk/researchgroups/ and search for < name of research Group>.

For information about Research generally at UCLan please go to http://www.uclan.ac.uk/research/

All outputs in CLoK are protected by Intellectual Property Rights law, including Copyright law. Copyright, IPR and Moral Rights for the works on this site are retained by the individual authors and/or other copyright owners. Terms and conditions for use of this material are defined in the policies page.

\section{CLoK}

Central Lancashire online Knowledge www.clok.uclan.ac.uk

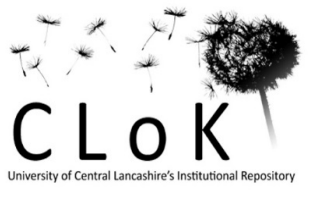




\section{Journal Pre-proof}

The effect of time and environmental conditions on Touch DNA

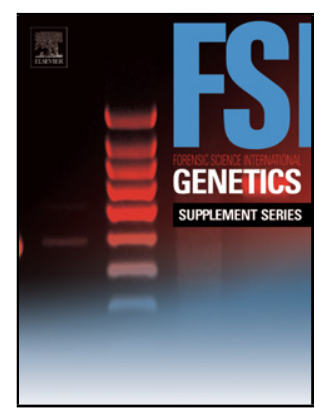

Salem K. Alketbi, W. Goodwin

PII:

S1875-1768(19)30197-0

DOI:

https://doi.org/10.1016/j.fsigss.2019.10.144

Reference:

FSIGSS 1777

To appear in:

Forensic Science International: Genetics Supplement Series

Received Date:

5 September 2019

Revised Date:

9 October 2019

Accepted Date:

11 October 2019

Please cite this article as: Alketbi SK, Goodwin W, The effect of time and environmental conditions on Touch DNA, Forensic Science International: Genetics Supplement Series (2019), doi: https://doi.org/10.1016/j.fsigss.2019.10.144

This is a PDF file of an article that has undergone enhancements after acceptance, such as the addition of a cover page and metadata, and formatting for readability, but it is not yet the definitive version of record. This version will undergo additional copyediting, typesetting and review before it is published in its final form, but we are providing this version to give early visibility of the article. Please note that, during the production process, errors may be discovered which could affect the content, and all legal disclaimers that apply to the journal pertain.

(C) 2019 Published by Elsevier. 


\section{The effect of time and environmental conditions on Touch DNA}

Salem K Alketbi ${ }^{1,2^{*}}$, Dr W. Goodwin ${ }^{1}$

${ }^{1}$ University of Central Lancashire, Preston, UK

${ }^{2}$ General Department of Forensic Science and Criminology, Dubai Police, Dubai, UAE

*Tel: 00447774141205; E-mail: alkitbe.11@hotmail.com

\section{Abstract}

Touch DNA analysis has become an important aspect of a forensic laboratory's workload and a crucial tool for investigators in many cases. However, there is a lack of research regarding the influence of environmental conditions on Touch DNA, which is proven to reduce traces of biological material in samples. This study investigated the influence of time between deposition and recovery of Touch DNA, as well as the impact of temperature and humidity on a range of porous and non-porous surfaces.

Keywords: Forensic science, Touch DNA, DNA recovery, PrepFiler Express BTA, AutoMate Express, Quantifiler ${ }^{\mathrm{TM}}$ Human DNA Quantification Kit

\section{Introduction}

Touch DNA analysis has become an important forensic technique and a crucial tool for investigators. However, there are many variables that affect the results of Trace DNA [1]. In addition to these factors, time and environmental conditions also affect Touch DNA. Although a few previous studies looked at the influence of time between deposition and recovery [2], there is a lack of research regarding the influence of environmental conditions, such as temperature and humidity, which have proven to reduce traces of biological material in samples [3].

Therefore, the aim of this study was to investigate the influence of time between deposition and recovery of Touch DNA and the impact of temperature and humidity on a range of porous and non-porous surfaces.

\section{Materials and methods}

\subsection{Experimental set up and deposition}

A selection of four surfaces (stainless steel, smooth non-porous; glass, smooth non-porous; textured wood, rough porous and textured plastic, rough non-porous) were chosen to replicate common items encountered in crime. All non-porous surfaces were cleaned by viricidal disinfectant ( $2 \%$ virkon) and ultraviolet radiation (UV) for $15 \mathrm{~min}$, and only textured wood was irradiated with UV for 25 min.

For DNA deposition, a participant was asked to wash his hands with antibacterial soap and refrain from undertaking any activity for $10 \mathrm{~min}$, then charge the fingers of both hands with eccrine sweat by touching behind their ears or forehead to load them with enough DNA. The participant was then asked to touch the surfaces using their index, middle, and ring fingers of both hands separately for deposition by applying medium pressure on a $5 \times 7 \mathrm{~cm}$ area of the surface for $1 \mathrm{~min}$. The same procedure was repeated on all surfaces for equal deposition on each surface. 


\subsection{Conditions}

To assess the effect of time in different environmental conditions, the selected surfaces were left for four time periods ( $3 \mathrm{~h}, 12 \mathrm{~h}, 24 \mathrm{~h}$ and one week) in three conditions (two replicates of samples for each condition): (a) Room temperature (RT) with moderate humidity $\left(20^{\circ} \mathrm{C}\right.$ to $\left.25{ }^{\circ} \mathrm{C} / 50 \%\right)$ ( $\mathrm{n}=32$ ), (b) High temperature $(\mathrm{HT})$ with moderate humidity $\left(40{ }^{\circ} \mathrm{C} / 50 \%\right)$ to simulate Dubai weather $(\mathrm{n}=32)$ and $(\mathrm{c})$ Low temperature (LT) with high humidity $\left(5^{\circ} \mathrm{C} / 78 \%\right)$ to simulate London weather $(n=32)$. The surfaces were stored in the oven and fridge for the HT and LT conditions respectively, and the temperature was monitored regularly using a hygrometer thermometer digital device. Ovens have very low humidity, so a plastic container of water was kept inside the oven to moderate the humidity.

\subsection{DNA recovery and extraction}

Samples were collected using a Copan $150 \mathrm{C}$ Cotton swab (Copan, Brescia, Italy) moistened with $100 \mu \mathrm{L}$ of sterile distilled water applied using a plastic spray bottle technique (developed in Dubai police forensic DNA lab; each single spray contains approximately $50 \mu \mathrm{L}$ ). Water was added when Touch DNA was collected at room temperature and high temperature, but not at low temperature because of the high surface humidity.

Full swabs head were used for extraction immediately after collection using PrepFiler Express BTA ${ }^{\mathrm{TM}}$ kit with AutoMate Express Forensic DNA Extraction System according to the manufacturer's instructions (Thermo Fisher Scientific) and the final extracted sample elution was $50 \mu \mathrm{L}$.

\subsection{DNA quantification, amplification and analysis}

Extracted samples were quantified using the Quantifiler ${ }^{\circledR}$ Human DNA Quantification Kit, QuantStudio 5 Real-Time PCR (qPCR) and HID Real-Time PCR analysis software v1.3 according to manufacturer's instructions (Thermo Fisher Scientific). Amplification were performed using the GlobalFiler ${ }^{\mathrm{TM}}$ PCR Amplification Kit (Thermo Fisher Scientific), following the 30 cycles protocol. The data were analysed using GeneMapper ${ }^{\circledR}$ ID-X Software Version 1.2 (Thermo Fisher Scientific). Statistical analysis on the tested variables was performed with RStudio using factorial analysis of variance (ANOVA). In ANOVA the $p$-value is derived from the F-distribution which is different for every pair of degree of freedom (df) values (F value $=$ variance of the variables means (Mean Square Between) / mean of the within variables variances (Mean Squared Error)). Blanks were taken from surfaces after sterilisation, and negative controls for the collection and extraction methods, all of which proved negative for DNA when quantified.

\section{Results and discussion}

At RT the amount of collected DNA from the selected surfaces (stainless steel, glass, textured wood and textured plastic) $(n=96)$ was not affected by time $\left(F_{3,16}=0.29, p=0.83\right)$, but at HT and LT the amount of collected DNA was significantly affected by time $\left(F_{3,48}=7.74, p<0.001\right)$, condition of the surfaces $\left(F_{2,48}=\right.$ $20.72, p<0.001)$, the interaction between surface type and conditions $\left(F_{6,48}=41.24, p<0.001\right)$, the interaction between conditions and time $\left(F_{6,48}=3.26, p<0.001\right)$ and the interaction between all the variables $\left(F_{18,48}=8.59, p<0.001\right)$.

Typically, more DNA is recovered from freshly touched surfaces when compared to surfaces stored over a long period of time [2], but the amount of recovered DNA is highly dependent on the conditions the touched object is exposed to. Over the four periods of time, the amount of DNA collected from each surface was stable at RT, but at HT and LT there was a slight change. Furthermore, the results showed that each surface behaved differently with the same conditions they were exposed to. This is caused by the interaction between each surface type with the different temperature and humidity (Figure 1). High heat can increase the rate of hydrolytic cleavage, leading to direct cleavage of the DNA strands due to drying. 
Some non-porous smooth surfaces, such as stainless steel and glass absorb heat. Even though the quantity is low, it is more effective in comparison to rough surfaces, as they are known to retain more DNA than smooth surfaces. Moreover, although moisture in a sample can lead to an increased rate of degradation, it may also increase DNA transfer [4]. In this case, more DNA was collected from glass and stainless steel in LT with high humidity when dry cotton swabs were used. In contrary, high humidity can lead to decrease the amount of DNA on porous surfaces such as wood because the water content is higher due to the water moving through the pores, which deteriorates traces of DNA left on the object.

Samples from stainless steel, textured plastic and textured wood stored at the three conditions for a week were amplified to validate the quality of samples collected. All the amplified samples produced full DNA profile, but there was some variation in the peak height between the samples collected for each surface at different conditions (Figure 2).

\section{Conclusion}

This study showed that time itself does not influence Touch DNA on the surfaces at room temperature, but the effect of different environmental conditions, such as low/high temperature low/high humidity can impact the persistence of DNA. Different type of surfaces interacts differently with outdoor environmental conditions, so it is important to consider when dealing with Touch DNA Profiling. Moreover, in real-life cases DNA sample contamination can occur when items have been left for long periods indoors or outdoors, so it is important to collect Touch DNA as soon as possible to ensure higher DNA yields and to avoid contamination, especially if the items were found outdoors.

\section{Conflict of interest}

None.

\section{Acknowledgements}

This study was approved by the General Department of Forensic Science and Criminology in Dubai Police and Ethical approval was granted by School of Forensic and Applied Sciences, and the University of Central Lancashire's Research Ethics Committee (ref. no. STEMH 912). Many thanks to COPAN DIAGNOSTICS INC. for supporting this experiment with free swabs, and to ThermoFisher Scientific ${ }^{\mathrm{TM}}$ for the discounts on their products.

\section{References}

1. S.K. Alketbi, The Affecting Factors of Touch DNA. Journal of Forensic Research. 9(3) (2018) 424.

2. C.J. Frégeau, C.M. Lett, and R.M. Fourney, Validation of a DNA IQ ${ }^{\mathrm{TM}}$-based extraction method for TECAN robotic liquid handling workstations for processing casework. Forensic Science International: Genetics. 4(5) (2010) 292-304.

3. J.J. Raymond, S.J. Walsh, R.A. van Oorschot, et al. Assessing trace DNA evidence from a residential burglary: abundance, transfer and persistence. Forensic Science International: Genetics Supplement Series. 1(1) (2008) 442-443.

4. M. Goray, R.J. Mitchell and R.A. van Oorschot, Investigation of secondary DNA transfer of skin cells under controlled test conditions. Legal medicine. 12(3) (2010) 117-120. 

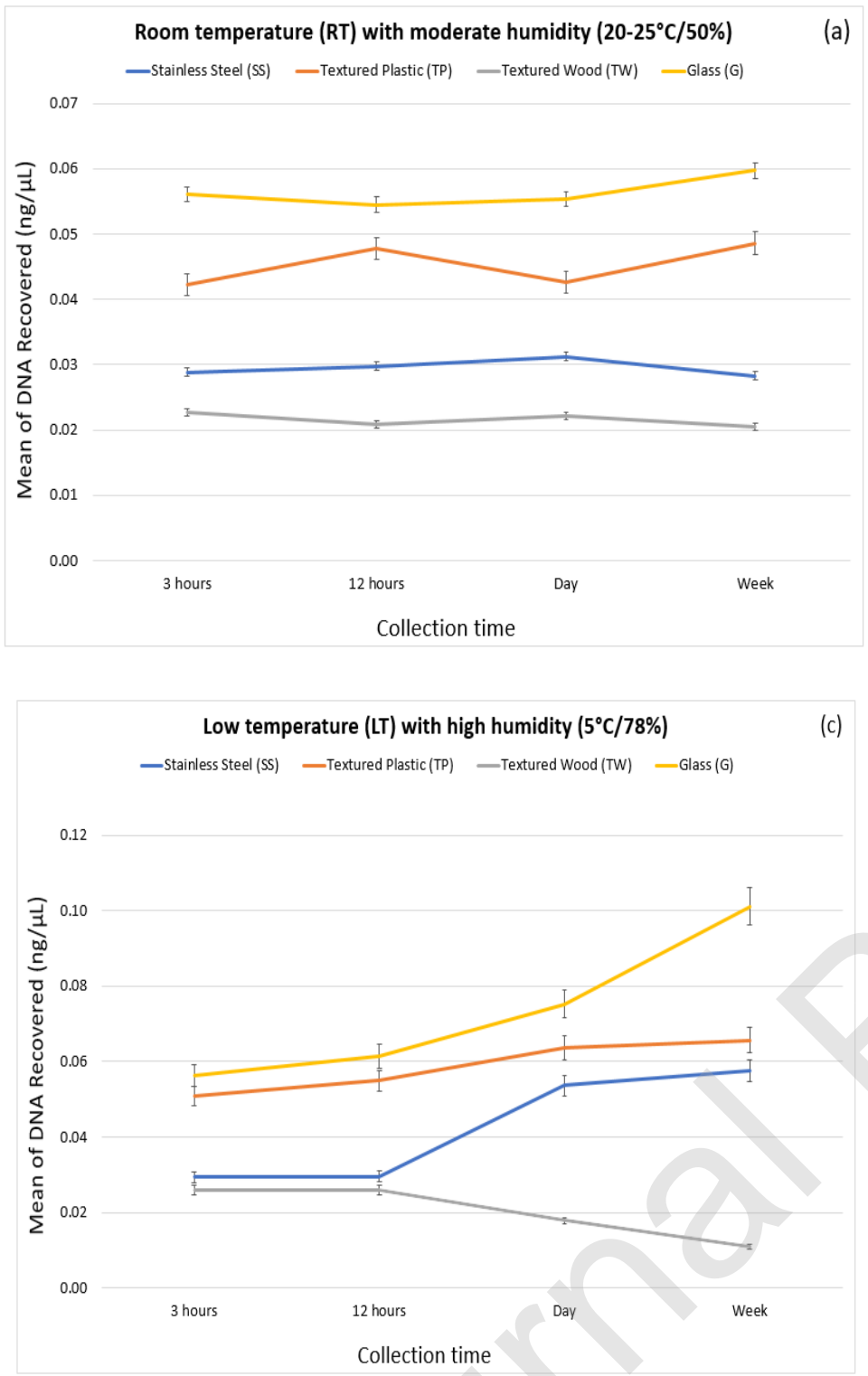

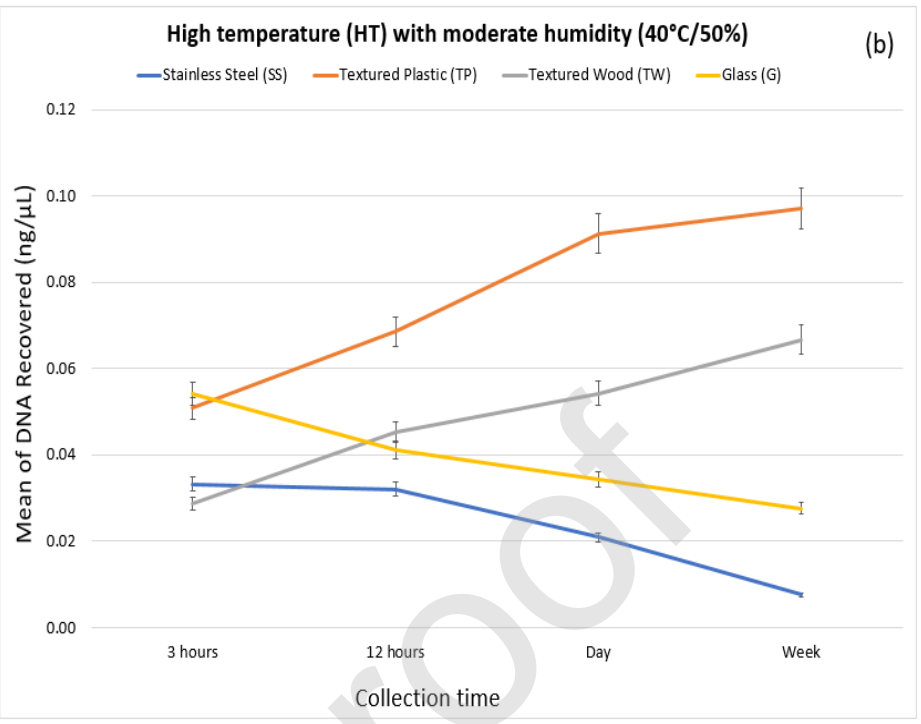

Figure 1 - The amount of DNA collected from the selected surfaces over four periods at three different conditions; $\mathrm{RT}^{\mathrm{a}}(\mathrm{n}=32), \mathrm{HT}^{\mathrm{b}}(\mathrm{n}=32)$ and $\mathrm{LT}$ ${ }^{c}(n=32)$. The amount of DNA collected from glass and stainless steel decreased over time in HT, and increased in LT. In contrast, the amount of DNA collected from textured plastic increased in $\mathrm{HT}$, and it was slightly stable in LT. Contrary to the glass the amount of DNA collected from textured wood increased in HT and decreased in LT. Error bars represent $95 \%$ confidence intervals. 
STAINLESS STEEL

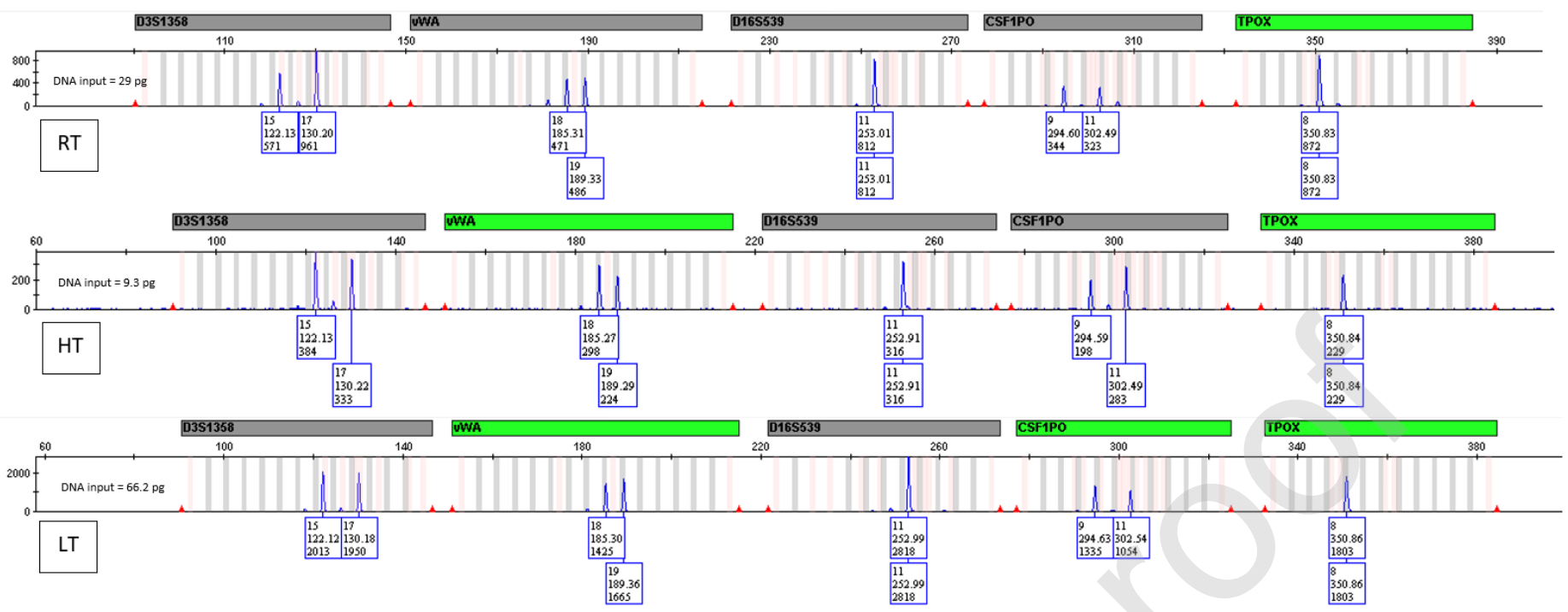

Figure 2 - Electropherograms of samples collected from stainless steel, at room temperature (RT), high temperature (HT) and low temperature (LT) over a week. The profiles show the difference in peaks height between the three conditions at 5 autosomal STR loci (D3S1358, vWA, D16S539, CSF1PO, TPOX). 